\title{
From the urban project to the participative public space project: A historical approach
}

\section{Del proyecto urbano al proyecto de espacio público participativo: Un enfoque histórico}

\author{
DOI: 10.17981/mod.arq.cuc.24.1.2020.04
}

Artículo. Fecha de Recepción: 28/12/2019. Fecha de Aceptación: 03/03/2020.

\author{
Samuel Esteban Padilla Llano \\ Universidad de la Costa. Barranquilla (Colombia) \\ spadilla@cuc.edu.com
}

Para citar este artículo:

Padilla, S. (2020). From the urban project to the participative public space project: A historical approach, $M O D U L O$ ARQUITECTURA CUC, no. 24, pp. 67-82, 2020. DOI: http://doi.org/10.17981/mod.arq.cuc.24.1.2020.04

Abstract

This article makes a chronological tour of the main city-making models, from classic to current times, to arrive at the conclusion that citizen participation in decision-making processes on urban projects has ended up conditioning the current working models of the territory, particularly in terms of urban production. Despite the inconsistency between what the broad body of knowledge on cities (Lexis) establishes for the development of citizenship and the often defended and cited citizen rights, and the practice (praxis) of participation, we find that processes that are promoted as being inclusive and with a collective work approach end up becoming, either through omission, lack of knowledge, inexperience or despotism, models that conceal hierarchical power structures and that deny urban equity and justice in public space projects.

Keywords: City models; citizen participation; public space; urban project

\section{Resumen}

En este artículo se hace un recorrido cronológico por los principales modelos de construcción de ciudades, desde la época clásica hasta la actual, para llegar a la conclusión de que la participación ciudadana en los procesos de toma de decisiones sobre proyectos urbanos ha terminado por condicionar los actuales modelos de funcionamiento del territorio, especialmente en lo que se refiere a la producción urbana. A pesar de la inconsistencia entre lo que el amplio cuerpo de conocimiento sobre las ciudades (Lexis) establece para el desarrollo de la ciudadanía y los derechos ciudadanos muchas veces defendidos y citados, y la práctica (praxis) de la participación, encontramos que los procesos que se promueven como inclusivos y con un enfoque de trabajo colectivo terminan convirtiéndose, ya sea por omisión, desconocimiento, inexperiencia o despotismo, en modelos que ocultan estructuras jerárquicas de poder y que niegan la equidad y la justicia urbana en los proyectos de espacio público.

Palabras clave: Modelos de ciudad; participación ciudadana; espacio público; proyecto urban 


\section{INTRODUCTION}

\section{Theoretical context}

The urban project emerged initially in the contemporary era as a comprehensive approach towards urban regeneration, at a time when some of the main guiding principles of critical and projective thought on urban planning were born, particularly in the context of the post-war periods of the mid- $20^{\text {th }}$ century. At the opposite end, towards the participative public space project, is proposed as a statement of intent to rethink cities more in terms of the unequal and complex social relationships that affect not only the use of the city, but also its form and configuration and the interaction and interlocution of citizens, when formulating and executing urban (and public space) projects.

From the urban theory point of view there are two interrelated focus themes regarding the development of cities: the morphology of the city and the relationships of citizens with the spaces and environments where public life takes place in common with others (Capel, 1975; de Solá-Morales, 2007; Castell, 1974; Borja, 2013; Brandão, 2014; Remesar, Vidal \& Salas, 2016, among others). A substantial part of this body of knowledge focuses on the study of the city in the contemporary era (shortly before the Declaration of Independence of the United States and the French Revolution), but especially following the rapid industrialization process that took place during the $19^{\text {th }}$ century, when the most paradigmatic city reform and growth plans emerged and which have become the foundations for subsequent urban planning models.
The urban evolution and transformation processes experienced by cities in the $19^{\text {th }}$ century, especially in Europe, and in the $20^{\text {th }}$ century in many cities throughout the world, have made them powerful paradigms that have influenced in one way or another the approaches of the development models that are currently used city in planning efforts. Many of these urban processes have been put into practice through a series of plans, programs and projects of different types, which have been the result of dissimilar political, economic, cultural or social situations, thereby setting a direction for intervention in the inhabited areas of the cities.

\section{From the modern era \\ to the contemporary era}

During the $19^{\text {th }}$ century, a few visionary urban planners led large expansion projects for older cities, such as Ildefonso Cerdà in Barcelona (1859), Georges-Eugène Haussmann in Paris (1852), Joseph Bazalguette in London (1848), and Carlos María de Castro in Madrid (1860). They all influenced to a certain extent later models such as the Kalff Plan (1878) of Jan Kalff or the Zuid Plan (1915) of Hendrik Petrus Berlage, both in Amsterdam, or in the north American context, a prime example is the Burnham Plan of the city of Chicago laid out by Daniel Burnham and Edward Bennett (1909), which recovered some of the criteria used by Haussmann in Paris. Their focus was on "esthetics", influenced by the Beautiful City movement of the early $20^{\text {th }}$ century and the emergence of modernist schools. 
As a result, many other urban development and expansion plans were drawn up, as transformative processes aimed at providing long-term solutions, mainly to address issues such as unhealthy living conditions, over-crowding, marginalization and the disarticulation of urban areas with the emerging peripheries of the cities of the time.

In the $20^{\text {th }}$ century new approaches were explored in urban planning and especially in architecture, based on the esthetic, formal and spatial values of the city; the social conditions of the environment, i.e. housing and the spaces for citizens to socialize, but also a wide range of instruments specified through international agreements, charters and other documents that currently form the basis for the theoretical models for urban action and zoning (Athens Charter, housing laws, charters of citizen participation and rights, among others we will further discuss below). However, as demonstrated by the congresses of CIAM, a theoretical void remains between architecture and urbanism, compounded by improper interpretation of the instruments and charters on urbanism, in many cases erudite discussions on the manner in which cities should be developed and transformed. Such void has been stretched to the limit, and even today it represents a major issue for the production of cities (de Solá-Morales, 2007).

But the fact that the city of the $20^{\text {th }}$ century was unable to consolidate all the intentions set forth in the documentary and instrumental base was also due to the various wars that took place, the anomie of political representation and sys- tems of government, the predominance of the private over the common good, inadequate development and implementation of strategies aimed at consolidating certain practices from a globalized perspective of cities, all of which have in some way run against social justice and urban balance.

In this regard, sanitation problems in industrialized cities and the largely unfinished urban plans were confronted with the new tenets of architecture and city planning. Starting in the 1930s new layouts were drawn for the new road networks, and the modern movement took a functional approach towards the organization of cities, based on the distribution of land according to land usage and the functions of buildings.

Consequently, the functional approach sought to eliminate the conflicts inherited from the historic cities and from subsequent periods, such as sanitation and over-crowding, and the emerging elements and infrastructure in cities, such as the automobile and railway systems, and the space these artifacts required for passing through or for commuting between the city and its neighboring areas. But despite these elements that were intended to promote order, the strategy was unable to resolve the problems caused by the unbalance between urban growth, the consolidation of cities, the development of society in all its spheres, and much less contribute to the urban and social cohesion of the cities.

This city zoning of the early $20^{\text {th }}$ century, which came to its most critical point (socially) in the second half of the century, effectively became the 
basis for the urban social movements of the 1960s and 1970s, which were structured and focused on developing policies to redress the unbalances that singular architecture and urbanization at the service of the organization of the territory by use and function had produced on urban living in the cities (Castell, 1974).

The cities of the $21^{\text {st }}$ century continue to carry all this baggage, displaying politically fragile and socially disperse realities. They face high levels of urban and social inequality, an unbalanced distribution of the economy and major issues regarding management of urban resources and equitable access to basic services. Despite much experimentation and the search for more efficient and effective models, the afflictions from the past continue to persist, including certain despotism in terms of city planning, of intervening urban spaces and generating comprehensive development policies.

In a different vein, the notion of urban project as a working environment in the city was only consolidated in the mid- $20^{\text {th }}$ century as a strategy to recover the areas, particularly in the aftermath of World War I (1914-1918) and World War II (1939-1945), and continued to be an effective tool to regenerate cities and reconvert the widespread urban conflicts that derived into and/or were reproduced in the war scenarios. However, the conditions of oppression (dictatorships) or devastation that affected the lives of the citizens in many European cities were largely responsible for directing urban development towards strategic planning processes, covering the layout, the road infrastructure for motor vehicle traffic and functional distribution, though not necessarily from an approach that took into consideration the population's community life.

As we pointed out earlier, much of the consolidation in this working area took place in the context of the modernist movement. During this period positions were radically polarized regarding many of the same issues that we continue to face today in terms of attempting to resolve the city's production processes. One of the clearest examples of the above is the issue of housing construction, involving building of large residential complexes. Even though these featured novel architectural and esthetic models and formal/spatial exploration, the constraint that was imposed over time by the geographic allocations and the implicit functional "stratifications or divisions" produced sprawling and unarticulated cities in both physical and social terms.

All this led to the surge of city peripheral areas. The progressive growth of cities led to the configuration or neighborhoods and settlements that were far removed from the town centers. Two types of peripheral areas began to develop during city growth processes. On the one hand, there were new residential neighborhoods that were products of the Garden City model (Ed. Howard), which promoted the separation of select and privileged populations from the urban centers, in search for a much more "relaxed" lifestyle than the historical centers could offer, through still maintaining a link to the city through road networks and the use of automobiles. 


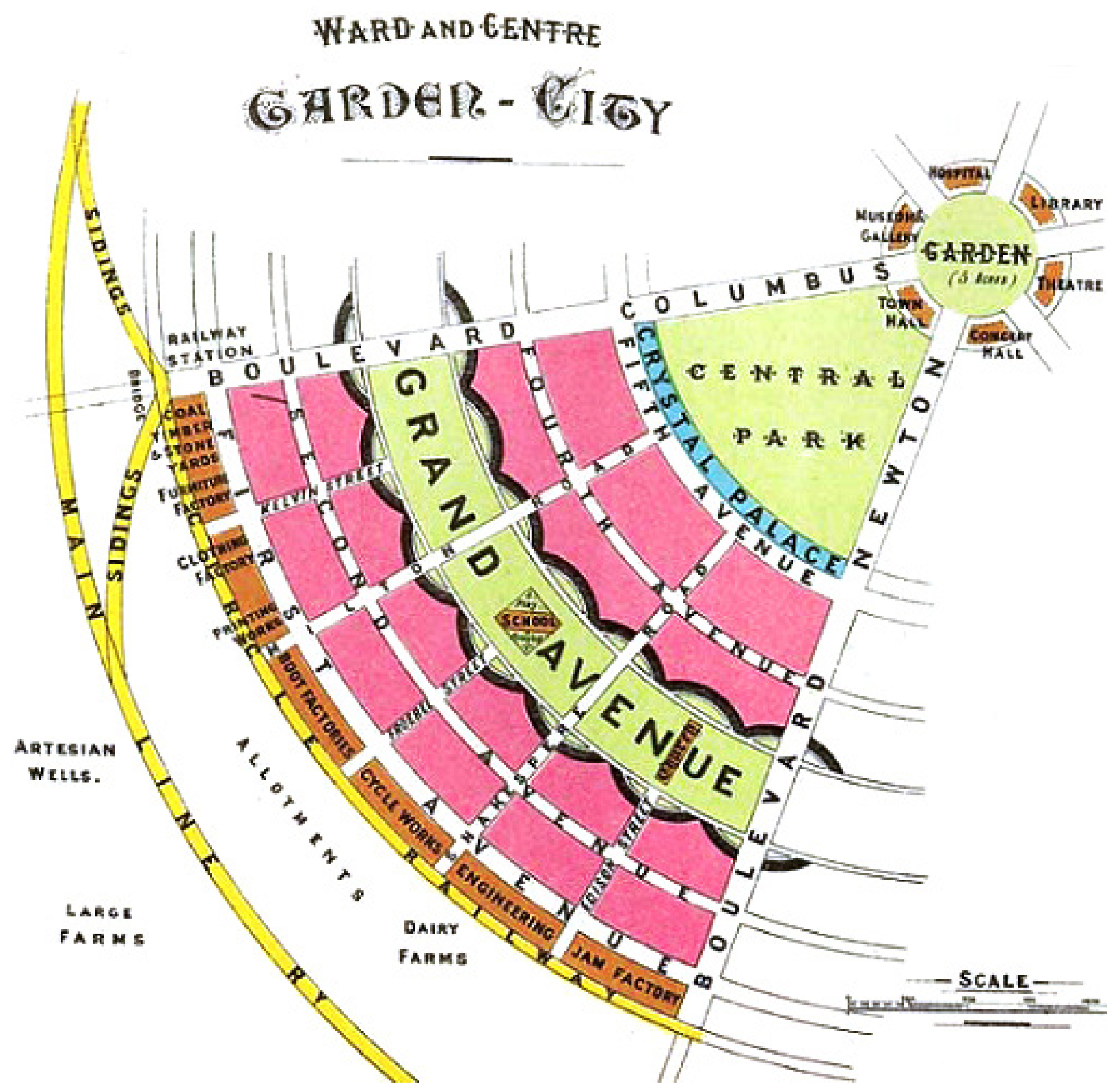

Figure 1. Layout of the garden-city, a functional distribution of a city proposed by Ebenezer Howard.

Source: http://urban-networks.blogspot.com.co/2016/02/el-modelo-original-de-la-ciudad-jardin.html 
On the other hand, a different type of periphery developed for populations with precarious economic resources and who were unable to gain access to urban lands, especially new arrivals to the large cities (through migration), and who normally settled in random and residual areas of the city, often near industries or other areas that were relatively near the consolidated urban area. Progressively peripheries of this type also included populations that were expelled from the gentrification processes resulting from speculative dynamics that cleared the way for profitable real estate development projects. It was in this historical context that many housing projects were developed to counteract such gentrification processes, through as we now know they created many more problems than comprehensive solutions in terms of improving people's living conditions (Remesar, Vidal \& Salas, 2016).

The imperative of building the industrial city had the consequence of segregating areas to separately locate industry, services and homes (Maderuelo, 2001, p. 19).

The cities of the first half of the $20^{\text {th }}$ century had learned from the effects of the expansion of cities outside the walls, and promoted new models of production that in essence attempted to connect the new environment of the "supra-city" with solutions such as the residential neighborhoods mentioned earlier, many of them developed by architects and urban planners who are currently recognized as icons of the concepts of cities, urbanism and architecture.
In this scale of the urban project, the planners were interested in consolidating new urban centers for the city that were connected to the urban networks and infrastructure, but that were sufficiently independent to drive their own development and cover all the needs of the local population of direct users of these new urban compounds (de SoláMorales, 2007).

However, the footprint left behind by some of the unfinished urban projects and developments was urban disarticulation, with social or economic imbalances and difficult access to basic services such as transportation or technical facilities for households (sewage, electricity, water, communications and other networks) and other basic urban resources that the city should normally provide. In this sense, the urban centers that were furthest removed from the financial, administrative or service centers were the ones with greatest deficiencies and problems.

\section{The scales of the project in the city}

All the above leads us to hypothesize that despite the great paradigms of urbanism, architecture and development, cities today still harbor many of the problems that for centuries have driven changes in how cities are thought of and the theoretical models that advocated strategies that seemed to be final solutions for matters such as urban unbalance and social justice represented in terms of equitable access to urban resources. But cities today, in addition to carrying the burdens from the past, need to specifically address new environmental, cultural, political, social and economic challenges in order to ensure equitable conditions for all citizens in the long term. 


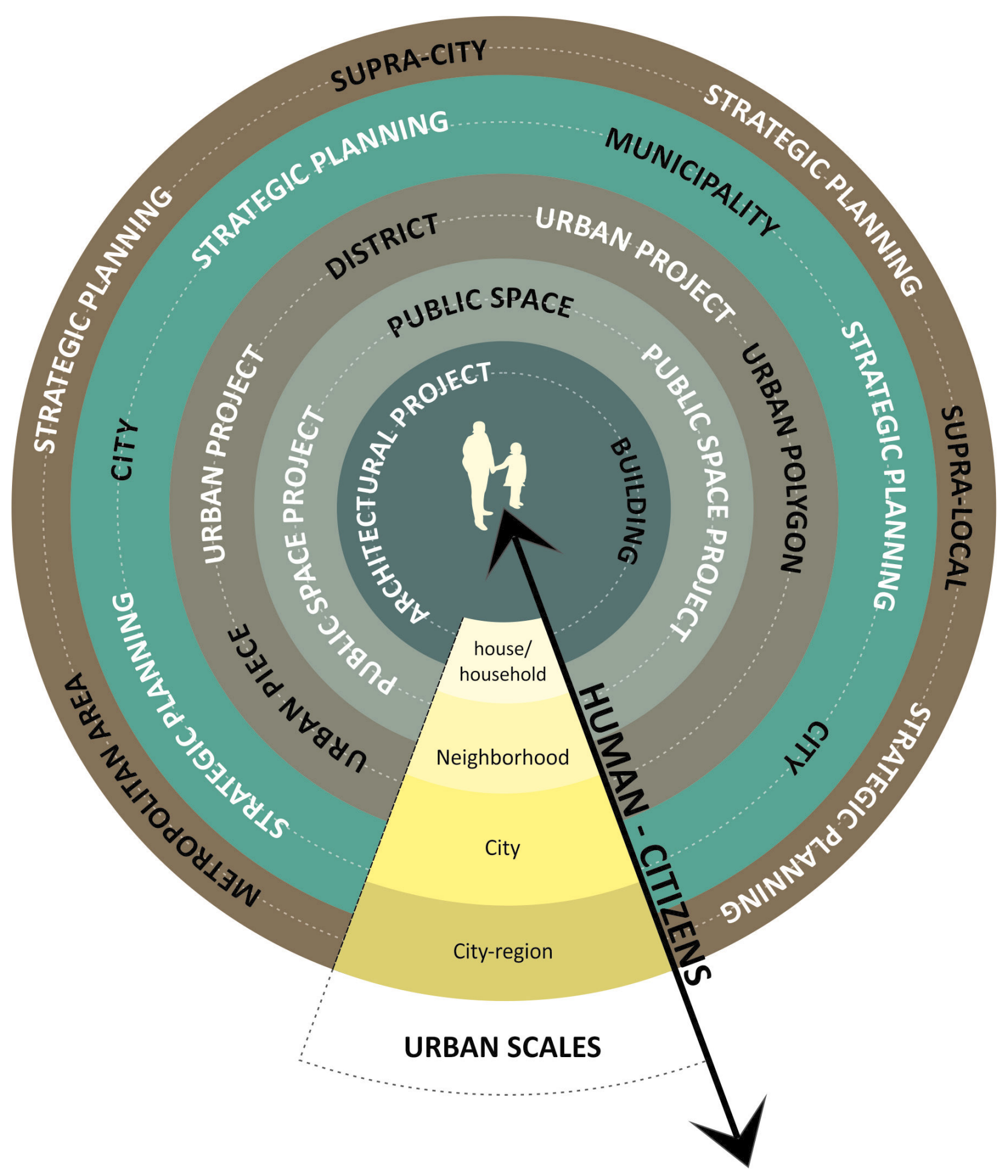

Figure 2. Planning scales according to current city management and production practices. Source: Padilla-Llano, 2015. 
In this sense, what is the challenge faced by the cities of today? To transcend beyond these zoning and planning models, which even though they are the foundations of the way of conceiving the city, they have also been complicit with extreme urban and social conflicts, mainly because the spheres in power have enabled or established certain working arrangements that often run against the interests of the citizens. The graph displays the scales of work in the city, according to the principles set forth in the early $20^{\text {th }}$ century.

According to such principles, there are four territorial scales: the house, the neighborhood, the city and the city-region. Through these the city projects are ordered: the architectural project, the urban project and the public space project. The upper scales are primarily subject to legal and regulatory frameworks, whereas the lower scales tend to have more formal or spatial frameworks.

It is often assumed that such scales are working environments that are independent from each other; however, what matters is where and how the accent on the city's production is placed. These scales should be closely related to each other. Architecture should be closely linked to the surrounding public spaces (not to the detriment of the private, public or collective spaces), but both must be built in urban entities that form part of a greater environment in combination with other entities.
The opposite also holds: planning should go beyond the system and theoretical base that it lays out over the cities; it needs to approach and relate to the scale of the citizens, and this means especially with the public spaces.

At present, one could say that there is a dualism in the planning models of cities. On the one hand is the strategic framework given by the overall vision of the cities, i.e. of their public policies for social, economic, urban and cultural development, etc., the scope of which goes beyond the local environment, as well as the decisions that, based on such vision, affect the city's form and organization. On the other hand, a second model is related with new emerging strategies that attempt to unlink dependency from traditional agents, clearing the way for more local-based and adapted experiences, not only in terms of the interaction between political entities and local agents, but also between the social and urban resources of the contexts they belong to (Portas, 2003).

The issue of the scales discussed at CIAM congresses has involved extensive theorization on urban intervention modalities but has also created difficulties on the "integrationist" sequence that should exist between the various scales. The principles, which on occasion are ambiguous, have deepened the theoretical void between what singular architecture intends and means and its relationship with 
urbanism. This void could well have been addressed through an intermediate scale between the strategic planning scale (metropolis, meta-polis, city-region, city, etc...) and the smaller scales such as the neighborhood and the house. In this sense, the urban project could become a correcting element for the inter-scale voids (de Solá-Morales, 1987).

Even though the urban project arose as an integrating force of situations of the city, of architecture and the public spaces, establishing guidelines adopted in the context of strategic planning, aimed at consolidating urban areas that the general guidelines of city planning cannot resolve, it has its own limitations in terms of finding consistency between what the citizens may intend with a given urban action and what the urban project design actually incorporates. It is here where the public space appears, at the scale that is nearest to the citizens. And in this sense, it is also where the praxis of citizen participation in city production processes finds its most suitable and effective venue for action.

The new way of thinking of architects and urban planners of the previous century, combined with the issue of projective transition between scales, has caused a shift in the discussion on how the city of today should be made. In other words, the praxis of urban project in the current context of cities displays the need to overcome the theoretical basis inherited from the urbanism of the $20^{\text {th }}$ century, and places the citizens' experience and expertise as the driver for the urban regeneration processes that lead to the development of more participative, and therefore more democratic, cities. In this new scenario the public spaces appear as the scale par excellence at which the citizens can become the active subject in the search to establish quality levels both in local developments, and in the places where life in common with others takes place (Habermas, 1999).

The citizen movements of today are characterized not only by a desire for political change similar to that promoted in the $1960 \mathrm{~s}$, 70s and $80 \mathrm{~s}$, but they also demand a more proactive presence in power and decision-making venues. There has been an undeniable shift in recent years in the ways of conceiving the city and urban development. Currently new strategies arise that seek to mitigate, on the one hand, the disaffection of citizens with the public administration and government institutions, but also, and especially, to legitimize practices aimed at reducing the urban imbalances caused by speculative growth and planning under the power of the private interests of certain segments of society. 


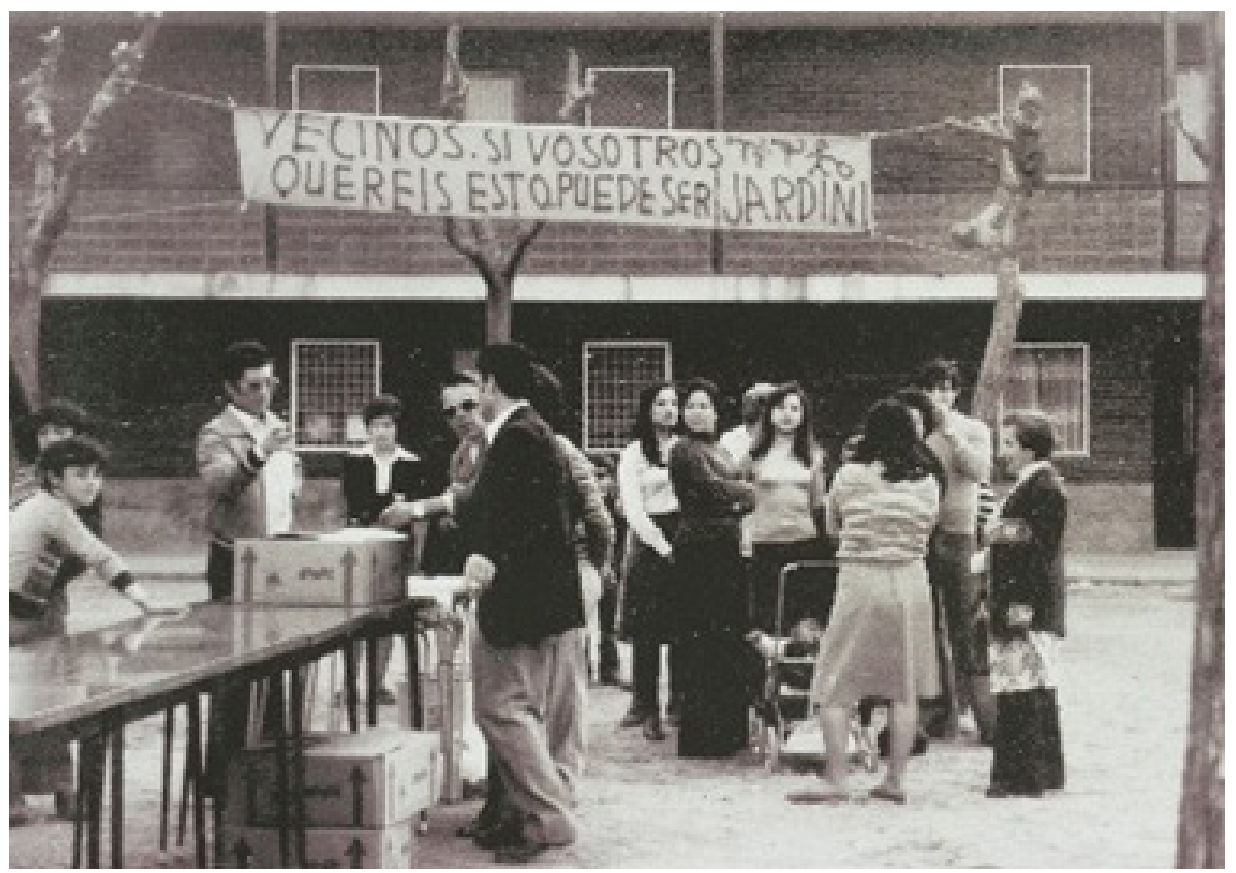

Figure 3. Neighborhood protest at Baro de Viver (Barcelona-Spain) demanding public spaces in the 1970s.

Source: CRPOLIS, Padilla-Llano, 2015.

The city today is perceived as a reality that is "diffuse, diverse, mutating, global, complex, uncertain", where the urban problems appear so complex that they require responses that are decisive, while at the same time flexible, in order to provide comprehensive solutions from the perspective of the citizens (Brandão, 2014, pp. 58-59). Cities today accumulate problems that are not addressed in a manner that is suitable for the times and that take into consideration the new social forces that have come to predominate in many cities of the world since the fall of the European dictatorships and the advent of democracy, but have as yet failed to completely eliminate the flaws of despotic planning. However, the appearance of new instruments and "charters" for the participative management of cities has opened new paths where citizens have found (or have been provided) means to have an influence on public decisions.

It may be difficult to define which city models are being followed today. Probably in a few decades the people of the future will know. What we can say is that it is increasingly evident that city management models need to run not only from the bottom to the top, but also in a cross cutting direction in a manner that brings government institutions and citizens closer together and where citizens begin to take on a leading role in their own development, thereby overturning the traditional hegemony of planning by only a few individuals. 
There is much talk nowadays about a new urbanism that is capable, on the one hand, of overcoming the issue of the scales of planning (associated with the rigidity present in many of the instruments), and on the other hand, of transforming the traditional practices of public administration, of urban planning professionals, but also of citizens as the main actors and users of the city. There is also a call for new ways of making a city, for an urbanism that is closer to the citizens, a new urbanism that is not only the product of exercises carried out by technicians and politicians, but where there is greater participation of the population in matters that have to do with life in community (Greene, Páez \& Sierralta, 2005). But this new urbanism is necessarily linked with a change in mentality on how to produce the city, where it is the result of a consensus between citizens, the development vision and the set of public policies created to this effect.

In other words, an urbanism that years ago Ascher (2004) proposed as an urbanism that is flexible (that can adapt to the contexts in which problems arise), reflexive (that it does not follow pre-conceived formulas), cautious (that it can foresee future problems and promote development over space and time), heterogeneous (that it takes into consideration a variety of solutions, needs, outlooks, visions, etc.), open (that it is not ruled only by science and professional technique), multisensory (that it generates identity of place and facilitates coexistence with others) and participative (that it is necessary the result of interaction between citizens, actors of all sectors of society). But all this is only possible with the confluence of many forces in the city: of knowledge, politics, culture, economics, democracy, etc.

The cities of today need a new urbanism that translates into a city conceived by and for its citizens, urban occurrences capable of transforming and improving the quality of life of its inhabitants. An urbanism where the city that is perceived represents a vision of quality of life, progress and development, where there is a relationship between citizens as individuals and as elements of a collective network; and lastly, an urbanism in which the city takes on its own life, in which citizens identify with the city, not only because it represents what they are and what they need, but also because it enables their full realization as individuals and communities (Lefevre, 2013).

Ultimately, an urbanism where the public space is an essential requirement to create cities that are friendlier and where citizen participation is the means for achieving it. The public space is an essential element of the life of cities as a place for coexistence, integration, sharing, leisure, etc., which implies that urban projects must be conceived so as to contribute to the improvement of the quality of life of the people, and especially to help reduce the existing gap between traditional city design practices and the new emerging arrangements of citizen mobilization. 


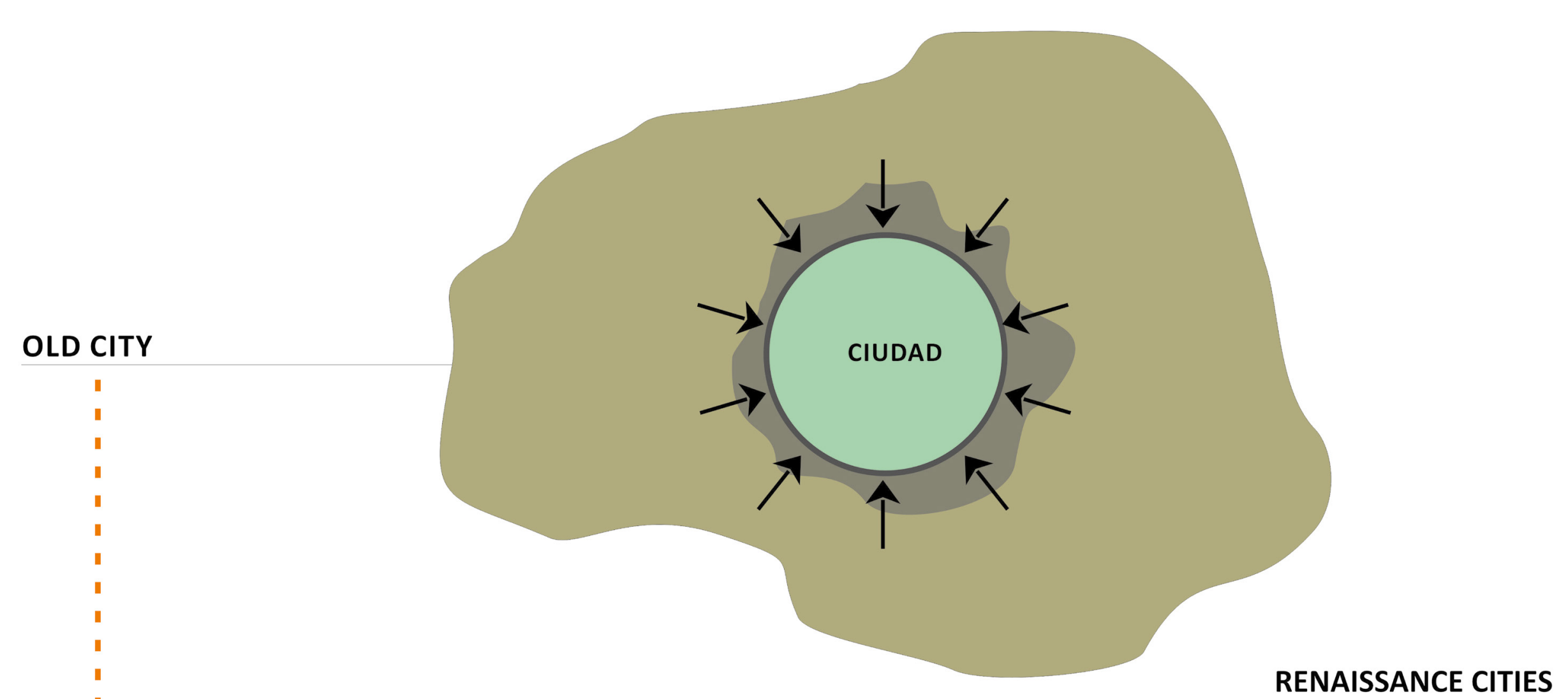
Mid-19th century up to industrialization

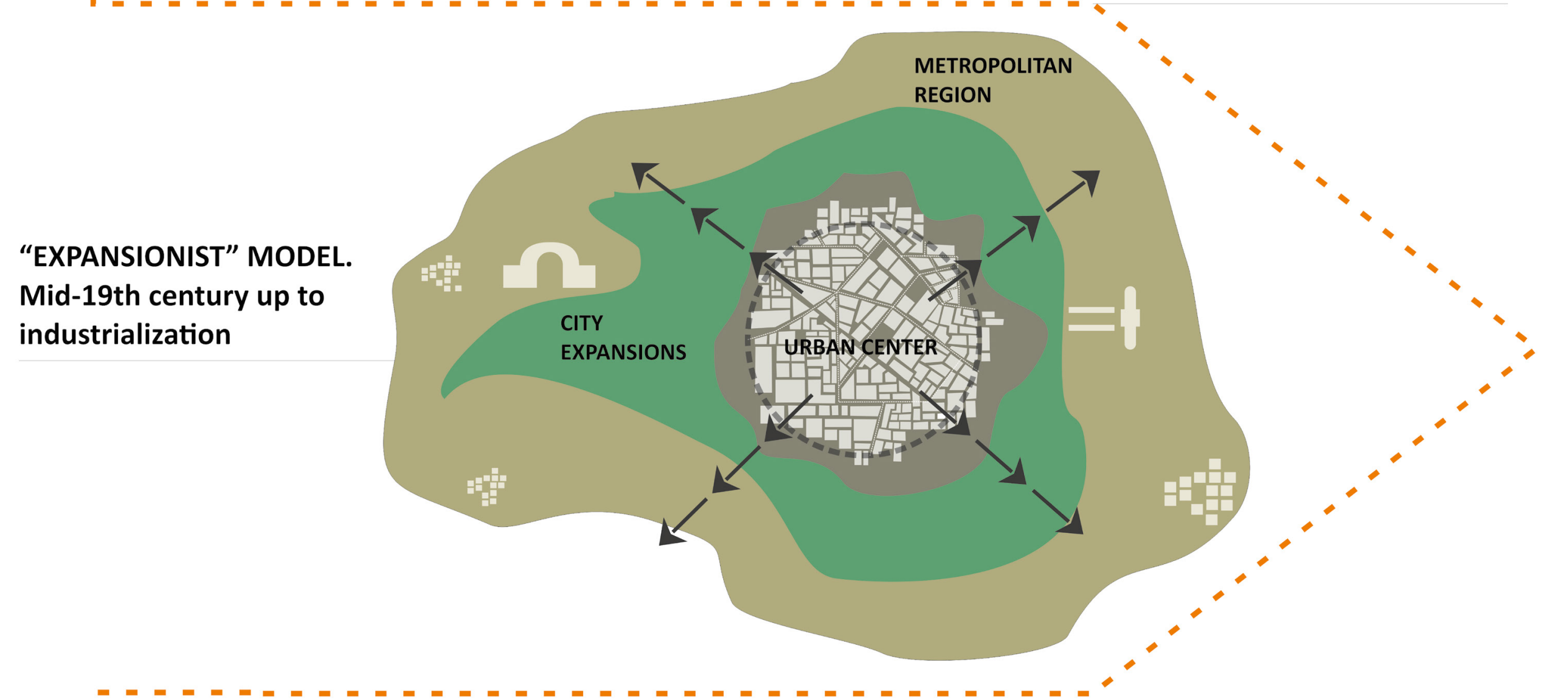

Figure 4. City models: from the old city to present Source: Padilla-Llano, 2015.

INDUSTRIALIZATION. Late 19th century, FUNCTIONALIST MODEL early 20th

century (diffuse and fragmented city)

"INTEGRATIONIST" MODEL

Second half of the 20th

century and early 21st

century (seeking a compact
city and new urban centers)
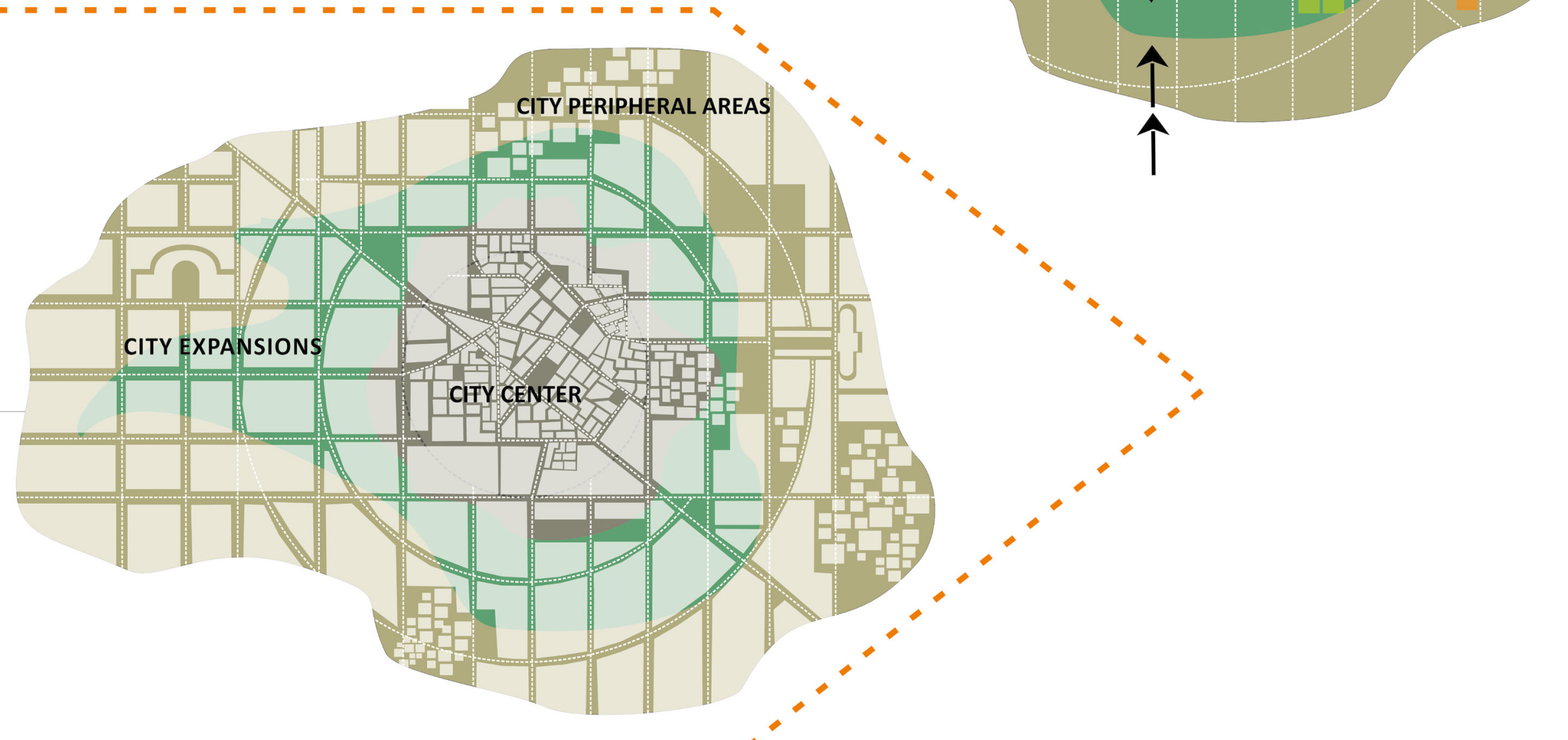

"BRANCH city or City of adjectives" (sustainable, smartBut, which will be the MODEL OF THE CITY OF TODAY cities, global-cities, etc.) | Brand city or city of adjectives:

(sustainable, Smart-cities, Global-Cities, inclusive,

tactical urbanism, urban acupuncture, participative urbanism, etc.) 


\section{Conclusions}

The public space is the venue par excellence for the establishment of relationship between the city and its citizens, the space where the various actors coexist, and consequently where synergies should presumably exist between the aspirations and projections of both parties. Citizen participation, in this sense, becomes a mechanism to undertake these production processes, where the public space is the focus of the processes where the resulting outcomes are diverse and may therefore be both tangible and intangible. Some of these may be deliberately included as objectives during the processes, while others may arise spontaneously through citizen participation. Consequently, the public space project is both an outcome of the production processes, and at the same time a document (or stage) developed before the conceived public space materializes.

Currently the public space is one of the contributing elements to the quality of urban life. Its condition of advertising grants citizens the freedom to democratically act and interact in it, jointly with the other citizens, to decide, promote and safeguard matters related to equity, social justice and urban balance in all its dimensions. Currently the public space is an important issue in citizen debates; it has political connotations, in the sense that exercising citizenship and advocating the right to the city are related to and are discussed primarily in connection with the public spaces.
In sum, we believe it is possible to ensure the quality of city production processes, especially regarding public spaces as drivers or primary focus areas for urban regeneration processes, if and only if projects are defined based on the effective and balanced inclusion of citizens in decision-making processes, including layout decisions (design) of public spaces.

Democracy in the city involves much more that citizens' votes in political and government elections; it also involves their inclusion in the various decision-making scenarios (so-called participatory) regarding the spaces where urban life takes place (public spaces, equipment, housing, etc.) and in general in any matter in the public's interest. In this sense, it can be said that "the quality of the public space is an essential test to assess citizen democracy (...) public spaces are the ones that express the progress or setbacks of democracy, both in political and social and cultural dimensions. (...) it is where solidarity is built and where conflicts are voiced, where demands arise, and aspirations are contrasted with the public policies and private initiatives. And it is in public spaces where dissolutory or exclusionary dynamics of the cities of today become visible, by their presence or absence" (Borja, 2013, p. 112).

Is clear that the urban project is a complex entity in the processes of city making. Therefore, it should not the result of the work of just one area of knowledge. The urban project (that include the public space projects) must be a response complete and complex, based in the interactiv- 
ity and heterogeneity of knowledge. This, from a perspective holistic to provide solutions to the diverse urban issue, thus ensuring the coverage of all perspectives, needs and dreams, achieving more appropriate projects to the community (Águas, 2014).

The urban and public space projects must be the result of an interdisciplinary process, that know as co-production. This type of processes involves professional actors, in the same level of non-professionals. All of them from several disciplines and sectors of society (public and private institutions, and others from third sector), political actors (public administration), social actors (local community leaders and volunteers), and the population in general. This refers to the coproduction of the public space through a timeline that marks five moments: (1) co-idea element, (2) co-designed, (3) co-intervened, (4) co-materialized, (5) co-managed. The "co" in this case, suggests a notion of shared work between different stakeholders, a distributed workload between all actors linked to the process and decisions making in a compelled collective way to make the public spaces.

Additionally, the implementation of citizen participation in the design of public spaces and of the urban project determines to a great extent the success of their results, both in physical (in reference to the constructed area) and non-physical terms (in reference specifically to the built environment: aspects related to citizen dynamics that are established, activated or reactivated based on the projects), as long as the strategies go beyond the narrow specifics and are true blueprints for development at the local scale and consequently of the general environment of the cities.

Even though participation has become a matter of fashion (Marchioni, 1994) ${ }^{1}$, it is necessary to undertake real and open participative projects that become an opportunity to overcome the nefarious and conflictive realities produced by the inadequate praxis of the actors who make and produce cities, always refocusing activities in favor of improving the quality of life of the cities and their citizens. But, in our context, "participation should not be understood today, as fashionable way in the management of cities. It must be seen instead as an everyday life activity, a natural act in the common life in common with others that pursuits the collective welfare. Today participation is involved in and for almost everything, but there are few times in which there is real citizens participation" (Padilla-Llano, 2015, p. 373).

The democratic quality of a city is assessed through the system of relationships between urban actors to manage, think about and decide on the way to inhabit and live in community with others. In this sense the public space is the key element to examine the system of relationships between the various sectors of society to which the various actors who intervene in the production of the city belong.

${ }^{1}$ Marchioni (1994) claimed that participation had become a matter of fashion, but precisely the fact that the concept is so widely used leads to suspect it is generating the contrary: the lack of confidence in the joint work of public management institutions and the groups of citizens (professionals, technicians or academics) who approach the communities to undertake the processes of leading interactive processes around the projects (Padilla-Llano, 2015). 


\section{REFERENCES}

Águas, S. (2014). Práticas emergentes no design do artefacto urbano: interdisciplinaridade e co-design. On the w@terfront, (32), 47-61. Retrieved from http://www. raco.cat/index.php/Waterfront/article/ download/281595/369429

Ascher, F. (2004). Los nuevos principios del urbanismo. El fin de las ciudades no está a la orden del día. Madrid: Alianza Editorial.

Borja, J. (2013). Revolución urbana y derechos ciudadanos. Madrid: Alianza Editorial.

Brandão, P. (2014). Diseño Urbano e Interdisciplinariedad. On the w@terfront, (29), 58-72. Retrieved from http://raco.cat/index. php/Waterfront/article/view/276667

Capel, H. (1975). La definición de lo urbano. Estudios geográficos, 36(138), 265-302. Retrieved from http://www.ub.edu/geocrit/ sv-33.htm

Castell, M. (1974). Movimientos Sociales Urbanos. México, D.F.: Siglo XXI.

de Solá-Morales, M. (2007). La segunda historia del proyecto urbano. Dearq, (1), 30-41. https://doi.org/10.18389/dearq1.2007.03

Habermas, J. (1999). La Inclusión del otro: estudios de teoría política. Barcelona: Paidós.

Greene, R., Páez, P. \& Sierralta, C. (2005). La ciudad es el mejor invento humano/ Entrevista a Horacio Capel. Bifurcaciones, (3). 1-7. Available from http://www.bifurcaciones. cl/2005/06/entrevista-horacio-capel/
Lefevre, H. (2013). La Producción del Espacio. Madrid: Capitán Swing.

Marchioni, M. (1994). La utopía posible: la intervención comunitaria en las nuevas condiciones sociales. La Laguna: Benchomo. Retrieved from http://dialnet.unirioja.es/ servlet/libro?codigo $=137198$

Padilla-Llano, S. (2015). Producción de espacio público [X] Participación ciudadana. El proyecto de espacio público resultado de procesos de participación ciudadana. [Tesis doctoral]. Universitat de Barcelona, Barcelona, España. Consultado en http://diposit.ub.edu/ dspace/handle/2445/66978

Portas, N. (2003). El surgimiento del proyecto urbano. Perspectivas Urbanas, (3). Retrieved from http://hdl.handle.net/2099/555

Remesar, A., Vidal, T. \& Salas, X. (2016). Urban Governance and Creative Participation in Public Space and Public Art. In, A. Remesar, The Art of Urban Design in Urban Regeneration. Interdisciplinarity, Policies, Governance, Public Space (55-90). Barcelona: Edicions de la Universitat de Barcelona. https://doi.org/10.13140/RG.2.1.4098.4723 